\title{
Process Improvement for Value Creation: a Case of Health Care Organization
}

\author{
Ramune Ciarniene, Milita Vienazindiene, Sergej Vojtovic
}

\author{
Kaunas University of Technology \\ K. Donelaicio st. 73, LT-44029, Kaunas, Lithuania \\ E-mail.ramune.ciarniene@ktu.lt, milita.vienazindiene@ktu.lt
}

University of A. Dubcek in Trencin

Studentska 3, 91150 Trencin, Slovakia

E-mail.sergej.vojtovic@tnuni.sk

cross $^{\text {ref }}$ http://dx.doi.org/10.5755/j01.ee.28.1.16601

\begin{abstract}
Every organization can be viewed as a set of processes and activities that are structured to satisfy customers' needs and expectations. The pressure of global competition, technology progress, increasing product and service complexity, and strong customer orientation force organizations to improve processes and their capability to create and deliver value. The fundamental goal of health care sector is added value for patients. The paper aims to develop a conceptual framework for healthcare processes improvement from the viewpoint of value creation. Based on systematic and comparative analysis of scientific literature, authors of the paper present the theoretical model of processes improvement for value creation from patient and organization perspectives. Value for patient is reflected in better access to services, time and cost reduction, quality improvement, convenience, and satisfaction. From organization perspective this leads to quality improvement, waste elimination and, finally, to a competitive advantage. Empirical research was conducted at outpatient clinic reception. 360 degree empirical research was applied during it including all parts interested, namely outpatient clinic's administration representatives, employees and patients. There were identified problematic areas of outpatient clinic's reception work processes and suggestions for processes improvement presented.
\end{abstract}

Keywords: Processes, Process Improvement, Value Creation, Health Care, Outpatient Clinic.

\section{Introduction}

Nowadays organizations all over the world are facing increasing pressure from customers and competitors. Organizations strive to achieve more with less in order to satisfy increasing demands from their customers, respond to new opportunities in the marketplace, meet pressures for profitability, and to build capabilities for improved performance over time (Morrison, 2015). Every organization that is competing with one another can be viewed as a set of processes and activities that are structured to satisfy customers' needs and expectations (Matthews, 2013; Pekkola \& Ukko, 2016). Processes lie at the heart of everything that organizations do to maintain their existence and grow (Dalmaris, 2007). This forces companies to implement new strategies for processes improvement to enhance their competitiveness in the global market (Chena, 2010).

While focusing on business processes is not new, it has achieved some kind of "vogue" in the past several years (Holtzman, 2011). Processes and their improvement concepts, tools and techniques were analyzed by Dalmaris (2007), Lepak et al. (2007), Langabeer et al. (2009), Brandao de Souza (2009), Does et al. (2009), Bowman and Ambrosini (2010), Chena (2010), McAlearney et al. (2011), de Mast et al. (2011), Brandao de Souza and Pidd (2011), Schiuma and Carlucci (2012), Tvedt et al. (2012), Boyer et al. (2012), Kumar et al. (2013), Matthews (2013), Svagzdiene et al. (2013), Antony (2014), Ciarniene and Vienazindiene (2015), Gardner et al. (2015), Morrison
(2015), Vessella (2015), Pekkola and Ukko (2016), and by other researchers.

Chena et al. (2010), Brandao de Souza (2009); Brandao de Souza and Pidd (2011), Kumar et al. (2013) Antony (2014), Ciarniene and Vienazindiene (2015) analyzed Lean concept as a tool for processes and performance improvement.

De Chernatony and Harris (2000), Lepak et al. (2007), Bowman and Ambrosini (2007), Bowman and Ambrosini (2010), Porter (2010), Matthews (2013), Schiuma and Carlucci (2012), Vveinhardt and Andriukaitiene (2014), Vveinhardt and Gulbovaite (2016), Pekkola and Ukko (2016) concentrated on value creation processes; Dalmaris (2007) analyzed improvement of knowledge-intensive processes.

Carayon et al. (2006), Brandao de Souza (2009); Does et al. (2009), Langabeer et al. (2009), Brandao de Souza and Pidd (2011), McAlearney et al. (2011), de Mast et al. (2011), Tvedt et al. (2012), Boyer et al. (2012), Gardner et al. (2015) researched different aspects of process improvement in healthcare.

The paper aims to develop a conceptual framework for healthcare processes improvement from the viewpoint of value creation.

Methods of the research: systematic and comparative analysis of scientific literature; observation, interview; qualitative research, logical abstraction and conclusion generation, and statistical analysis. 


\section{Theoretical Background}

Process improvement can been defined as "the critical analysis and radical redesign of existing processes to achieve breakthrough improvements in performance measures, such as cost reduction, time reduction or quality improvement" (Holtzman, 2011, 53 p.). According to Vessella (2015) process improvement is the proactive task of identifying, analyzing and improving upon existing processes within an organization for increased optimization. Diagnosis of the process reveals improvement opportunities such as identifying bottlenecks, optimizing capacity and utilization of staff and equipment, reducing cost and waiting times, improving a process's reliability, reducing cycle times per task by optimizing work methods and procedures (de Mast et al., 2011).

In the process improvement paradigm, improvement originates in mapping processes and measuring carefully defined quality characteristics and performance metrics (de Mast et al., 2011). The results of process improvement can be measured in the enhancement of product or service quality, customer satisfaction and loyalty, development of the skills of employees, cost reduction, increased productivity, efficiency, and profit (Holtzman, 2011; Vessella, 2015).

Practitioners and researchers in the field of operations management examine the use of policies, practices and techniques associated with process improvement. Many methods for process improvement and management have been proposed over the years (Dalmaris, 2007).

The results of retrospective scientific literature analysis disclosed such concepts as Lean, benchmarking, Six Sigma, theory of constraints (TOC), Reengineering, Total quality management (TQM), DMAIC (define, measure, analyze, improve, control) and other methods focusing on different areas of improvement for the best results of organizational performance and value creation.

Achieving high value for patients must become the overarching goal of health care delivery (Porter, 2010). The key for long-term success of an organization is to identify processes that create value and those that do not. Value creation is another central concept in the management literature for both micro level (individual and group) and macro level (organization theory and strategic management) research (Bowman \& Ambrosini, 2010; Lepak et al., 2007). Bowman and Ambrosini (2010) suggest that value is not a single phenomenon; it is multi-faceted and means different things to different stakeholders of the organization, specifically its customers, suppliers, employees and investors.

According to Matthews (2013) "a successful unique value proposition has three ingredients: the value can be easily determined in the mind of the customer, the value is relevant in the life of the customer, and some aspect uniquely differentiates the offering from all offerings from other organizations".

Value creation rests on cause-and-effect chains activated by the development of organizational resources through processes improvement (Schiuma \& Carlucci, 2012).

Based on scientific literature analysis, authors present a theoretical model of processes improvement for value creation (see figure 1).

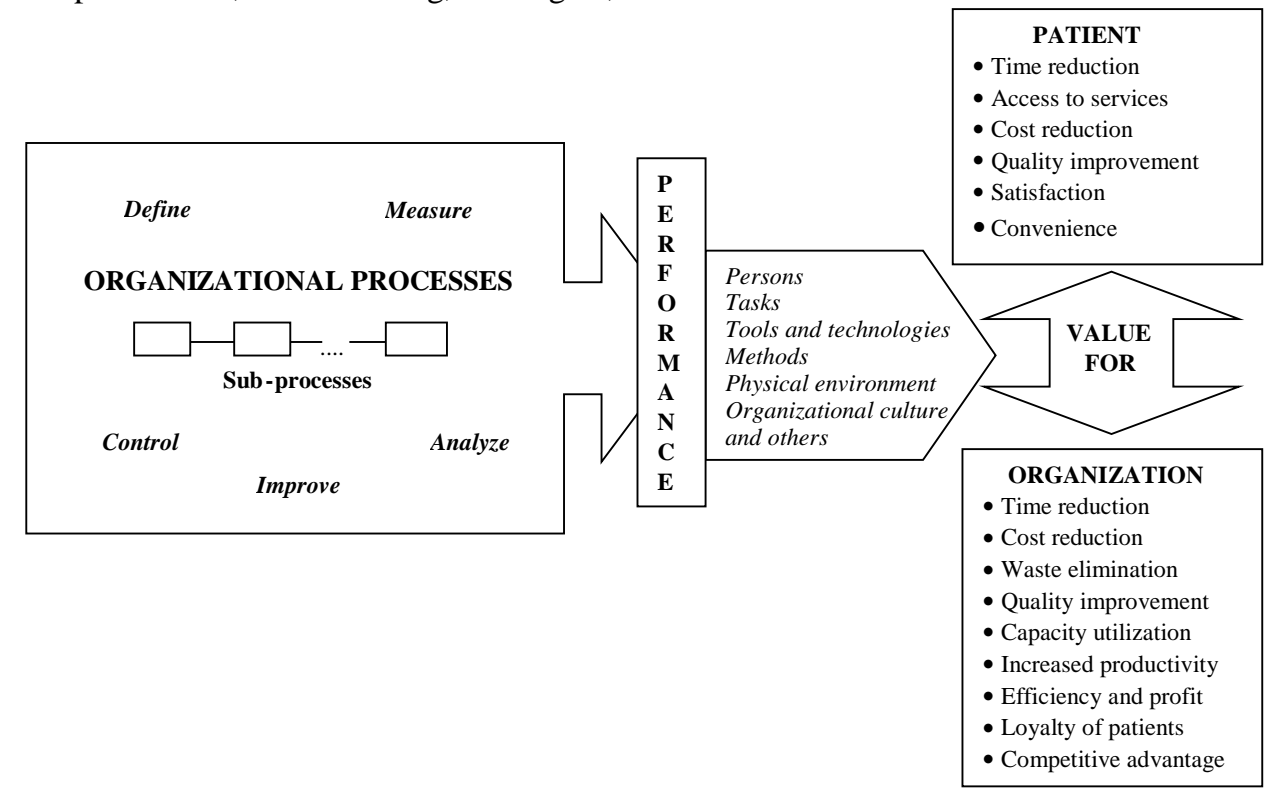

Figure 1. The Theoretical Model of Processes Improvement for Value Creation

The processes within health care institution consist of a big variety of sub-processes. An employee of a healthcare institution performs a wide range of tasks using various methods, tools and technologies under particular organizational conditions and within a specific physical environment. The interactions between the various components of process influence capability to create and deliver value for customer and organization.
Aiming for value creation organizational processes must be improved and controlled. Process improvement involves the following steps: developing process objectives according to company mission; identification of the process and sub-processes to be improved; measuring and analysis of the existing process; design and control of the new process. 
The results of process improvement can be measured in the increased access to services, better convenience and safety, higher quality, customer satisfaction and loyalty, cost containment, increased productivity and efficiency. All of this finally leads to a competitive advantage of health care organization.

\section{Research Methodology}

Research goal - having analysed work processes of outpatient clinic's reception, to present suggestions for their improvement.

Research methods. To reach the goal there was applied a 360 degree research including all parts interested: outpatient clinic's administration representatives, employees and patients.

There were applied following methods for the research:

- Unstructured reconnaissance interview with representatives of administration in striving to become familiar with existing situation and problems. In order to reach the goal there was created a questionnaire consisting of 15 questions.

- Analysis of information presentation on a website: content of website, approach to contacts, informational content, presentment of text, usefulness, clearness, convenience and expedience of navigation in point of view of patient.

- Qualitative research - analysis of content of internal documents. Following were analysed: work schedules of information manager and medical receptionist for the period of January - March 2016; data of registration of phone registration calls for the period of December 2015 March 2016, schedule of order of consultations in 2015; instructions of positions of information manager and medical receptionist.

- Deep interview with outpatient clinic's medical receptionists and information manager. The goal of this interview was to identify the main problems arising in the process of patients' registration.

Observation of reception's work processes and patients' flow. The aim was to determine problematic areas, expression of reception's division of labour, state of material and information supply, use of working time. Observation is being executed by recording with stopwatch operations of reception's employees and patients' actions and their duration. Observation is being performed in different weekdays and working hours, given different flows of patients and different number of employees at reception.

Research approach: Value to patient - value to outpatient clinic.

Research time: The research was executed in March April 2016.

\section{Research Findings}

Reconnaissance interview allowed clearing up the main problematic areas in outpatient clinic's reception work and their negative consequences.

Interview was participated by management director, head of consultative clinic and head of internal medical audit department, administrator of consultative clinic and other representatives of administration.

During reconnaissance interview with representatives of administration, there were identified 5 main problem areas. Detailing of problem areas and their negative consequences to outpatient clinic are presented in Table 1.

Table 1

Problem areas of Reception's Work in Point of View of Outpatient Clinic's Administration

\begin{tabular}{|c|c|c|}
\hline Problem area & Explanation of problem area & $\begin{array}{r}\text { Negative consequences } \\
\end{array}$ \\
\hline Patients' phone registration & $\begin{array}{l}\text { It is complicated for patients to get through } \\
\text { reception's phone numbers. } \\
\text { Big number of unanswered phone calls. }\end{array}$ & $\begin{array}{l}\text { Complaints of unsatisfied patients. } \\
\text { Lost patients. } \\
\text { Loss of financing. }\end{array}$ \\
\hline $\begin{array}{l}\text { Unduly presented text of } \\
\text { answerphone during phone } \\
\text { registration }\end{array}$ & $\begin{array}{l}\text { When medical receptionist is not answering a call, } \\
\text { answerphone asks to leave a message that is not being } \\
\text { responded actually. }\end{array}$ & $\begin{array}{l}\text { Mislead patients. } \\
\text { Unsatisfied patients. }\end{array}$ \\
\hline $\begin{array}{l}\text { Logistics of personal medical } \\
\text { histories (cards) }\end{array}$ & $\begin{array}{l}\text { Usually personal medical histories are being carried } \\
\text { to doctors-specialists by medical receptionists having } \\
\text { accumulated their particular number. }\end{array}$ & $\begin{array}{l}\text { Doctors-specialists have to wait for cards. } \\
\text { Detained doctors-specialists and patients. }\end{array}$ \\
\hline $\begin{array}{l}\text { Presentation of work schedules of } \\
\text { doctors }\end{array}$ & $\begin{array}{l}\text { Schedules of consultations of doctors-specialists are } \\
\text { being presented to medical receptionists too late. }\end{array}$ & $\begin{array}{l}\text { Patients do not get information on schedules of } \\
\text { consultations of doctors-specialists on time. } \\
\text { Unsatisfied patients. }\end{array}$ \\
\hline $\begin{array}{l}\text { Un-cancelled consultations of } \\
\text { registered patients }\end{array}$ & $\begin{array}{l}\text { Patients registered by phone or internet do not come } \\
\text { to consultations and do not inform about intendancy } \\
\text { in advance (not cancel consultations). About } 200 \\
\text { patients per month on the average do not come to } \\
\text { consultations or examinations. }\end{array}$ & $\begin{array}{l}\text { Inefficiently used working time of doctors- } \\
\text { specialists. } \\
\text { Unexecuted consultations as much as planned } \\
\text { /would be possible. }\end{array}$ \\
\hline Lack of doctors-specialists & $\begin{array}{l}\text { Lack of doctors-specialists. It is complicated for } \\
\text { patients to register for consultation on desired time; } \\
\text { they need to wait for a long time. }\end{array}$ & $\begin{array}{l}\text { Unserved, lost patients. } \\
\text { Loss of income. }\end{array}$ \\
\hline
\end{tabular}

With reference to the performed research, it can be stated that identified problematic areas in work of reception cause following main negative consequences: unsatisfied and mislead patients; detained doctorsspecialists and patients; lost potential patients, loss of income.
Analysis of Information Presentation on Website and Content of Internal Documents

Goal of this research stage - to reveal information supply and availability of reception's processes and documental regulation. 
Patient's registration - first experience on outpatient clinic and first step in a chain of value creation.

Patient can be registered for consultation of doctorspecialist or examination by one of the following ways: phone, e-mail, internet or on arrival.

Having analysed information presented on website, there were identified following problems:

- Unequal presentation of phone numbers.

- Un-informatively presented postal address of outpatient clinic.

- Segment of working time indicates only working hours, but there is not indicated that reception works on workdays only. Thus, patients are being misled; many unanswered calls were on rest-days and holidays.

- There is no one system while indicating specialities of doctors, references to sergu.lt in contact column and email are inactive.

- Information presented in column of contacts of doctors-specialists is unequal: in some there are indicated all four ways of registration and in others there are only some of them.

- While registering through sergu.lt, a column „Type and description of visit "indicates abbreviation IPR that is unclear and uninformative to patient.

- There are not presented outpatient clinic's formulations of mission, visions and strategical goals.

Having analysed work schedules of medical receptionists and information manager for the period of January - March 2016, it was noticed that during the first $30 \mathrm{~min}$. in the reception there works only one person, who is physically unable to greet arrived patients and register patients by two phone numbers. The same could be told about reception's last working hours at 18.00 -19.00 p.m., and at 17.00-19.00 p.m. on Fridays, when one person works in the registry as well.

Having analysed data of phone registration calls, it was determined:

- Patients use No. 1 more often than No. 2, which is confirmed by total number of calls (see Table 2), 10680 and 1857 correspondingly (data of 02.2016).

- Number of unanswered calls on both phone numbers is extremely big, 76 and 77 percent of all calls correspondingly. A result of that is unregistered and unsatisfied, possibly lost patients and loss of income.

- Having performed detailed analysis of phone calls for the period from 01.01.2016 until 09.03.2016, there was revealed that number of unanswered calls on both numbers exceeded 16000. It was determined that number of calls during non-working time (rest-days and holidays, end of work) amounted more than 220 calls, and patient hanged a phone without response in more than 770 cases.

- Having analysed number of calls according to reception's working hours, it was determined that the highest number of calls (both answered and unanswered) was noticed during the period from 8.00 a.m. to 14.00 a.m., though most employees of reception are working at that time.

- During the period when only one person works at reception, i.e. from 7.30 a.m. till 8.00 a.m., number of unanswered calls reaches 60 and more per day, and at 18.00-19.00 p.m. (17.00-19.00 p.m. on Fridays) - 80 and more.

Analysis of Data of Patients' Phone Registration

\begin{tabular}{|c|c|c|c|c|c|c|}
\hline \multirow{2}{*}{ Calls } & \multicolumn{2}{|c|}{12.2015} & \multicolumn{2}{|c|}{01.2016} & \multicolumn{2}{|c|}{02.2016} \\
\hline & Number & $\%$ & Number & $\%$ & Number & $\%$ \\
\hline \multicolumn{7}{|c|}{1} \\
\hline Answered calls & 2201 & $22,88 \%$ & 2506 & $22,65 \%$ & 2554 & $23,91 \%$ \\
\hline Unanswered calls & 7418 & $77,12 \%$ & 8560 & $77,35 \%$ & 8126 & $76,09 \%$ \\
\hline Total number of calls & 9619 & $100,00 \%$ & 11066 & $100,00 \%$ & 10680 & 100,00 \\
\hline \multicolumn{7}{|c|}{2} \\
\hline Answered calls & 419 & $23,46 \%$ & 414 & $21,42 \%$ & 416 & $22,40 \%$ \\
\hline Unanswered calls & 1367 & $76,54 \%$ & 1519 & $78,58 \%$ & 1441 & $77,60 \%$ \\
\hline Total number of calls & 1786 & $100,00 \%$ & 1933 & $100,00 \%$ & 1857 & $100,00 \%$ \\
\hline
\end{tabular}

Deep Interview with Employees of Outpatient Clinic's Reception

Goal of deep interview with employees of outpatient clinic's reception - to identify main problems arising in the process of patients' registration in point of view of reception's employees. Detailing of problem areas determined during the interview and their negative consequences on outpatient clinic are presented in Table 3.

Table 3

Problem Areas of Reception's Work in Point of View of Reception's Employees

\begin{tabular}{|l|l|l|}
\hline \multicolumn{1}{|c|}{ Problemic area } & \multicolumn{1}{|c|}{ Explanation of problemic area } & \multicolumn{1}{c|}{ Negative consequences } \\
\hline Lack of place & $\begin{array}{l}\text { Personal medical histories (cards) do not stow; } \\
\text { Lacking daylight, ventilation; }\end{array}$ & $\begin{array}{l}\text { Loss of time. } \\
\text { Inconvenience in registration operations. }\end{array}$ \\
\hline $\begin{array}{l}\text { Presentation of } \\
\text { work schedules of } \\
\text { doctors-specialists }\end{array}$ & $\begin{array}{l}\text { Doctors-specialists do not hold terms set for presentation of schedule of } \\
\text { consultations, present it too late. } \\
\text { Receptionists are detained in striving to get work schedules. }\end{array}$ & $\begin{array}{l}\text { Unsatisfied patients. } \\
\text { Lost patients. } \\
\text { Loss of time. }\end{array}$ \\
\hline Creation of tickets & $\begin{array}{l}\text { Creation of tickets requires additional time and concentration of } \\
\text { receptionists. }\end{array}$ & $\begin{array}{l}\text { Loss of time. } \\
\text { Inconvenience in registration operations. }\end{array}$ \\
\hline $\begin{array}{l}\text { Cancelling of } \\
\text { tickets }\end{array}$ & $\begin{array}{l}\text { Doctors cancel their consultation time. } \\
\text { Receptionists have immediately to cancel tickets and warn as well re- } \\
\text { register patients if possible. This work has to be urgently inserted between } \\
\text { other routine works. }\end{array}$ & $\begin{array}{l}\text { Loss of time. } \\
\text { Unsatisfied patients. } \\
\text { Lost patients. }\end{array}$ \\
\hline
\end{tabular}




\begin{tabular}{|l|l|l|}
\hline \multicolumn{1}{|c|}{ Problemic area } & \multicolumn{1}{|c|}{ Explanation of problemic area } & \multicolumn{1}{c|}{ Negative consequences } \\
\hline $\begin{array}{l}\text { Logistics of } \\
\text { personal medical } \\
\text { histories (cards) }\end{array}$ & $\begin{array}{l}\text { Often patients' personal medical histories (cards) are not being returned to } \\
\text { reception after consultations or examinations. }\end{array}$ & $\begin{array}{l}\text { Time expenditures for search of cards. } \\
\text { Unsatisfied patients. }\end{array}$ \\
\hline $\begin{array}{l}\text { Interference in } \\
\text { system of queue } \\
\text { management }\end{array}$ & $\begin{array}{l}\text { Often queue management system fails, sound signal disappears, queue's no. } \\
\text { does not renew in a screen, and computer needs to be restarted. It takes time } \\
\text { for patient to approach counter, receptionists have to call aloud }\end{array}$ & $\begin{array}{l}\text { Loss of time. } \\
\text { Inconvenience in registration operations. }\end{array}$ \\
\hline $\begin{array}{l}\text { Interference of } \\
\text { phone connection }\end{array}$ & $\begin{array}{l}\text { Time after time phone restarts, correspondingly, patients cannot get through } \\
\text { at that time. }\end{array}$ & $\begin{array}{l}\text { Loss of time. } \\
\text { Lost patients. }\end{array}$ \\
\hline $\begin{array}{l}\text { Noise in reception } \\
\text { room }\end{array}$ & $\begin{array}{l}\text { Noise in the room disturbs conversation of information manager and } \\
\text { medical receptionists with patient and his phone registration. }\end{array}$ & Inconvenience in registration operations. \\
\hline
\end{tabular}

Observation of Outpatient Clinic'S Patient Flow and Research of Reception'S Work Processes

Goal of this research stage - to reveal problem areas of patients' registration processes, expression of reception's division of labour, state of material and information supply, and use of working time.

During observation there was aimed to identify processes in point of view of patients, to see from patient's position how and what is preceded, and what is unacceptable or uncomfortable for patient, to reveal the activities that do not create added value.

Having performed observation of patient registration process and reception employees' work processes, there were determined main stages of the process. Figure 2 presents patient's registration process flowchart.

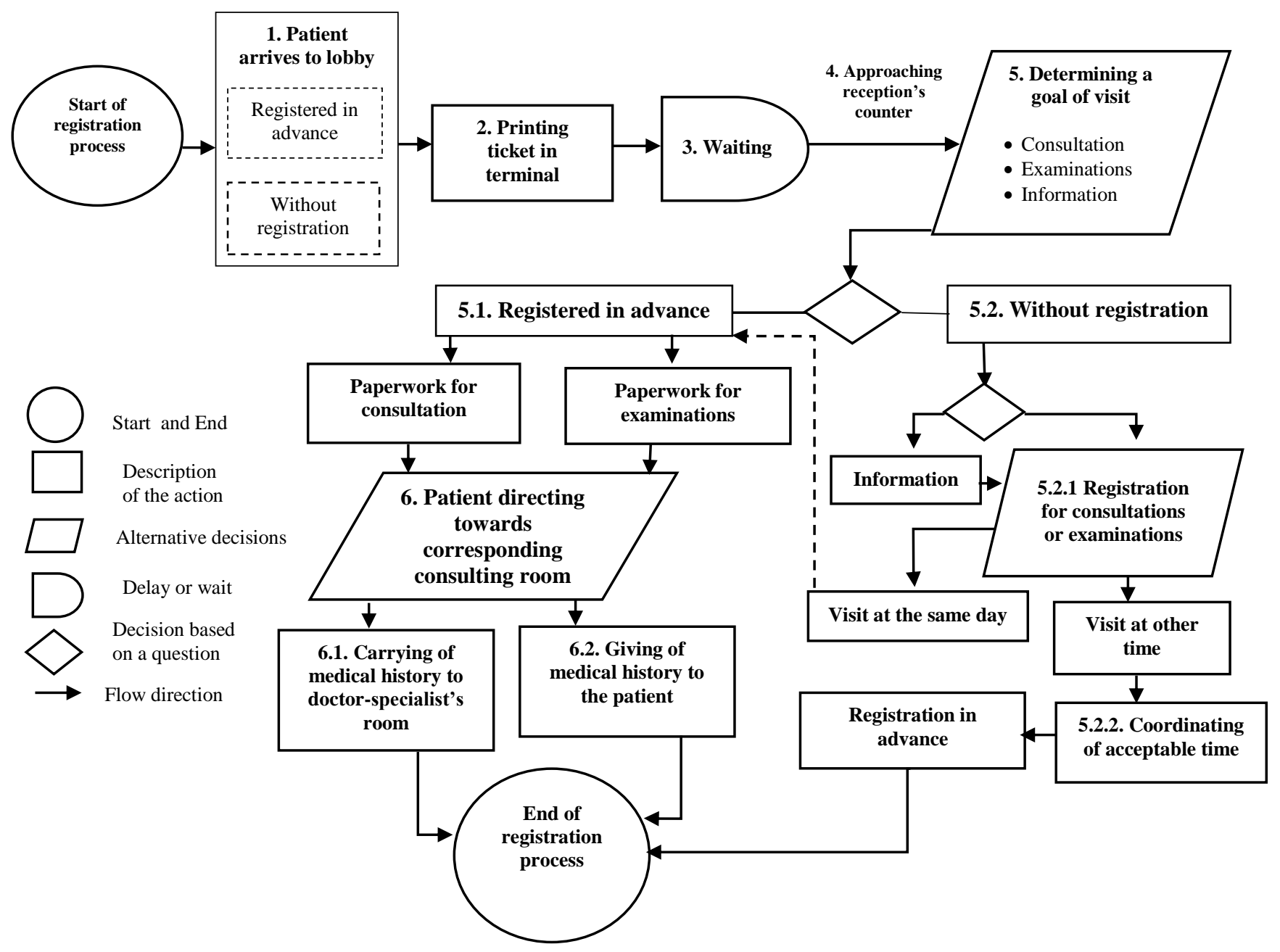

Figure 2. Patient's Registration Process Flowchart

Having performed observation, there was determined that independently on the fact if patient arrives having registration in advance or without it, from the moment of arriving to lobby till direction towards office of doctorspecialist patient's actions are not differing substantially. Good practise of other health care institutions shows that patients, who registered through sergu.lt, can arrive to doctor-specialist directly.

With reference to analysis of documents and having performed observations, there was determined that in outpatient clinic's reception there exist both formal and informal division of labour. 
1. Formal division of labour is expressed by following main forms:

- According to position. Positions are distinguished to medical receptionists and information managers.

- According to working time. Reception's employees' work according to work schedule created for every month by head nursing administrator and coordinated with head of subdivision.

2. Informal division of labour is expressed in agreement between reception's employees to share some work depending on their work schedule and employment:

- Patient phone registration.

- Carrying of personal medical histories (cards) to doctor-specialist.

- Archiving of personal medical histories (cards).

- Creation of tickets.

Having analysed material and information supply of work places, there were identified following problematic areas:

- Reception is lacking place for personal medical histories.

- During patients' rush hours, all 6 employees work at reception, though there are equipped only 5 work places.

- Often queue management system fails, sound signal disappears, and queue number is not renewed in the screen. Therefore, patients linger to approach the counter; receptionists have to call for patients aloud.
- Numeration of terminal tickets is continuous despite there are distinguished three positions: registration for consultation, examination, children and employees. Children and employees are serviced at the counter out of turn. This often causes dissatisfaction of other patients.

- Doctors-specialists are late with presentation of schedules for consultations; correspondingly "creation of tickets" and presentation of information on consultations for patients are late.

- Room and environmental noise disturb information manager and medical receptionists to talk with patient and his phone registration.

Having performed observation of medical receptionists' work, it was determined that main priority operations and operations that make the biggest part of workday time expenditures are following: registration of arriving patients (having registration in advance or without it); patients' registration by one of reception's public phone numbers; logistics of cards; presentation of information to arriving patients; creation of tickets; cancelling of tickets; registration of employees by internal phone; search for cards; archiving of cards; handling of examination results.

There was performed detailed analysis of two main operations: registration of arriving patients and patients' registration by reception's publicly indicated phone.

Table 4 presents data of observation of registration of arriving patients.

Table 4

Data of Observation of Registration of Arriving Patients

\begin{tabular}{|l|c|c|c|c|c|c|c|c|c|c|}
\hline Queue No. & 1 & 2 & 3 & 4 & 5 & 6 & 7 & 8 & 9 & 10 \\
\hline Duration, min. & 2.47 & 3.35 & 3.08 & 1.45 & 2.33 & 1.58 & 2.16 & 3.02 & 2.50 & 2.02 \\
\hline Queue No. & 11 & 12 & 13 & 14 & 15 & 16 & 17 & 18 & 19 & 20 \\
\hline Duration, min. & 2.30 & 3.01 & 2.05 & 2.58 & 2.08 & 2.33 & 7.59 & 2.57 & 3.03 & 3.09 \\
\hline
\end{tabular}

As it is seen from chronometric row data, duration of operation varies considerably enough from 1.45 to 7.59 min. Such considerable varying of durations was influenced by different factors:

- differences of patients and their communication;

- circumstances of patient's visit (if he had registered in advance or not);
- situations when receptionist has to search for card.

Having eliminating the least and the highest values from chronometric row, there was determined average duration of operation of registration of arriving patient $2.53 \mathrm{~min}$.

Table 5 presents data of observation of patients' registration by one of reception's public phone numbers.

Table 5

Data of Observation of Patient's Registration by one of Reception's Public Phone Numbers

\begin{tabular}{|l|c|c|c|c|c|c|c|c|c|c|}
\hline Queue No. & 1 & 2 & 3 & 4 & 5 & 6 & 7 & 8 & 9 & 10 \\
\hline Duration, min. & 1.47 & 1.16 & 2.01 & 1.42 & 1.33 & 2.00 & 1.46 & 1.22 & 1.50 & 1.42 \\
\hline Queue No. & 11 & 12 & 13 & 14 & 15 & 16 & 17 & 18 & 19 & 20 \\
\hline Duration, min. & 1.30 & 1.41 & 1.25 & 1.58 & 1.38 & 1.36 & 1.59 & 1.57 & 0.47 & 1.29 \\
\hline
\end{tabular}

Having eliminating the least and the highest values from chronometric row, there was determined average duration of patient's phone registration $-\mathbf{1 . 4 3} \mathbf{~ m i n}$.
Summarized data of reception's employees working time expenditures and their impact on value creation presented in Table 6.

Table 6

Summarized Data of Working Time Expenditures

\begin{tabular}{|l|l|l|l|}
\hline \multicolumn{1}{|c|}{ Operation } & \multicolumn{1}{|c|}{$\begin{array}{c}\text { Duration of operation/ } \\
\text { periodicity }\end{array}$} & $\begin{array}{c}\text { Type of working time expenditures } \\
\text { /Impact on value creation }\end{array}$ & \multicolumn{1}{c|}{ Notes } \\
\hline Registration of arriving patient & $2.53 \mathrm{~min}$. & Operational time/ Value creation & Priority operation \\
\hline Patient's registration by phone & $1.43 \mathrm{~min}$. & Operational time/ Value creation & Priority operation \\
\hline Logistics of cards & $\begin{array}{l}3.00-5.16 \mathrm{~min} . \\
\text { Cards are being carried every 10- } \\
15 \mathrm{~min} .\end{array}$ & Operational time/ Value creation & Priority operation \\
\hline
\end{tabular}


Inzinerine Ekonomika-Engineering Economics, 2017, 28(1), 79-87

\begin{tabular}{|l|l|l|l|}
\hline \multicolumn{1}{|c|}{ Operation } & \multicolumn{1}{|c|}{$\begin{array}{c}\text { Duration of operation/ } \\
\text { periodicity }\end{array}$} & $\begin{array}{c}\text { Type of working time expenditures } \\
\text { /Impact on value creation }\end{array}$ & \multicolumn{1}{|c|}{ Notes } \\
\hline $\begin{array}{l}\text { Presentation of information to } \\
\text { arriving patients }\end{array}$ & $0.29-2.01 \mathrm{~min}$. & Operational time/ Value creation & Priority operation \\
\hline $\begin{array}{l}\text { Presentation of information by } \\
\text { phone }\end{array}$ & $0.39-2.04 \mathrm{~min}$. & Operational time/ Value creation & Priority operation \\
\hline Creation of tickets & $\begin{array}{l}\text { Performed after reception of } \\
\text { information about doctors' work } \\
\text { schedules }\end{array}$ & Operational time/ Value creation & Priority operation \\
\hline Cancelling of tickets & $\begin{array}{l}\text { Performed after doctor's } \\
\text { information }\end{array}$ & Loss of time & Must be done urgently \\
\hline $\begin{array}{l}\text { Employees' registration by } \\
\text { internal phone }\end{array}$ & $1.05-2.00$ min. & Operational time/ Value creation & Priority operation \\
\hline Search of cards & To 10 min. & Loss of time & $\begin{array}{l}\text { When histories are not returned } \\
\text { to reception in time }\end{array}$ \\
\hline Archiving of cards & $\begin{array}{l}\text { Performed during time free from } \\
\text { priority operations }\end{array}$ & Pre-closing time / Value creation & Non-priority operation \\
\hline Handling of examination results & $\begin{array}{l}\text { Performed during time free from } \\
\text { priority operations }\end{array}$ & Pre-closing time / Value creation & Non-priority operation \\
\hline
\end{tabular}

Having performed 360 degree analysis of reception's work processes in aspect of value creation, Table 7 presents summarized problems identified during the research and suggested means for optimization of work processes.

Problems Identified During the Research and Suggestions for Work Processes Improvement

\begin{tabular}{|c|c|}
\hline Problem areas & Suggested means \\
\hline $\begin{array}{l}\text { Information presentation, clearness to } \\
\text { patient }\end{array}$ & $\begin{array}{l}\text { To change a text in answerphone by refusing proposals to call again in } 3 \text { min. and leave message. } \\
\text { To indicate that reception works only in workdays. } \\
\text { To apply one system while indicating specialities of doctors, names and methods of registration. } \\
\text { To make active references to sergu.lt and e-mail in contact columns. } \\
\text { To correct /explain abbreviation IPR. } \\
\text { To present on website formulations of outpatient clinic's mission, vision and strategical goals. } \\
\text { To change continuous numeration of tickets into numeration according to groups. }\end{array}$ \\
\hline $\begin{array}{l}\text { Work schedules of information } \\
\text { manager and medical receptionist }\end{array}$ & $\begin{array}{l}\text { To create work schedule so that at least two employees would work in reception during the indicated } \\
\text { period. }\end{array}$ \\
\hline Patients' registration by phone & $\begin{array}{l}\text { To establish centre of patients' phone registration calls, for example, by using neighbouring room. } \\
\text { To guarantee that during non-rush-hours patients would be registered by phone at least by one employee, } \\
\text { during rush hours - two. } \\
\text { Having displaced operations of phone registration into separate room the problem would be solved. }\end{array}$ \\
\hline Lack of place in reception room & $\begin{array}{l}\text { Part of personal medical histories should be displaced into the room of suggested call centre. } \\
\text { To equip two work places in the call centre and to leave four work places (as much as there are active } \\
\text { counters) in the reception part. } \\
\text { To transfer personal medical histories from paper into electronic form. }\end{array}$ \\
\hline $\begin{array}{l}\text { Schedules of consultations of doctors- } \\
\text { specialists }\end{array}$ & $\begin{array}{l}\text { To oblige doctors to present next month's consultations schedules until } 15 \text { day of the current month. } \\
\text { Given possibility, to present consultation schedules for the period longer than } 1 \text { month. }\end{array}$ \\
\hline $\begin{array}{l}\text { Interference of phone connection and } \\
\text { queue management system }\end{array}$ & To remove interference of phone connection and queue management system. \\
\hline $\begin{array}{l}\text { Logistics of personal medical histories } \\
\text { (cards) }\end{array}$ & $\begin{array}{l}\text { To oblige doctors and nurses to follow set order and to return cards to reception after consultation or } \\
\text { examination. }\end{array}$ \\
\hline $\begin{array}{l}\text { Un-cancelled consultations of } \\
\text { registered patients }\end{array}$ & $\begin{array}{l}\text { To stimulate patients to cancel consultations, given no possibility to arrive, by presenting information on } \\
\text { cancelling of consultation in contact column of doctors-specialists repeatedly. }\end{array}$ \\
\hline Registration process & $\begin{array}{l}\text { To create possibility for patients, who registered in advance through sergu.lt, to arrive directly to office of } \\
\text { doctor-specialist. }\end{array}$ \\
\hline
\end{tabular}

During applied 360 degree research, there were identified following problematic areas of outpatient clinic's reception work processes: information presentation and its clearness to patient; inaccuracies in internal documentation; work schedules of information manager and medical receptionist; inefficient patients' phone registration; lack of place in reception room; late presentation of consultation schedules of doctorsspecialists; interference of phone connection and queue management system; deficiency of logistics of personal medical histories (cards); un-cancelled consultations of registered patients; non value added activities in process of patient registration. With reference to performed research, it can be stated that identified problematic areas in reception's work cause following negative consequences: unsatisfied and misled patients; non value added processes, during which precious time of doctors-specialists and patients is delayed; lost potential patients, loss of income.

Having emphasizing creating value for patients, priority directions of actions in improvement of outpatient clinic's reception work processes would be following:

1. To establish patients' phone registration call centre.

2. To guarantee clearness, accuracy and timeliness of information presentation to patient. 
3. To create possibility for patients, who registered in advance through system sergu.lt, to arrive to office of doctor-specialist directly.

\section{Conclusions}

The pressure of global competition, technology progress, increasing product and service complexity, and strong customer orientation force health care organizations to improve their processes and capability to create and deliver value for a patient.

According to the conducted research, process improvement involves the following steps: developing process objectives according to company mission, identification of the process and sub-processes to be improved, measuring and mapping of the existing process, and design and control of the new process.

The results of process improvement reveals added value for patients, which can be measured by the increased access to services, better convenience and safety, higher quality, time reduction, and satisfaction. Health care organization gains loyalty from a patient, cost containment, increased productivity and efficiency. All of this finally leads to a competitive advantage.

According to the conducted 360 degree research, there were identified the following main problematic areas of outpatient clinic's reception work processes and non-value added activities: presentation of information to patient, inaccuracies in internal documentation, schedules of reception and consultations, inefficient patients' phone registration, technical problems with phone connection and queue management system, deficiency of logistics of personal medical histories, and un-cancelled consultations of registered patients.

Priority directions of actions in improvement of outpatient clinic's reception work processes would be establishing of patients' phone registration call centre, presenting of clear, accurate and timeliness information to patient, and avoiding duplications in patient registration process.

\section{References}

Antony, J. (2014). Readiness Factors for the Lean Six Sigma Journey in the Higher Education Sector. International Journal of Productivity and Performance Management, 63(2), 257-264. https://doi.org/10.1108/IJPPM-04-20130077

Boyer, K. K., Gardner, J. W., \& Schweikhart, S. (2012). Process Quality Improvement: An Examination of General vs. Outcome-specific Climate and Practices in Hospitals. Journal of Operations Management, 30, $325-339$. https://doi.org/10.1016/j.jom.2011.12.001

Bowman, C., \& Ambrosini, V. (2007). Identifying Valuable Resources. European Management Journal, 25(4), $320-9$. https://doi.org/10.1016/j.emj.2007.05.001

Bowman, C., \& Ambrosini, V. (2010). How Value is Created, Captured and Destroyed. European Business Review, 22(5), 479-495. http://dx.doi.org/10.1108/09555341011068903

Brandao de Souza, L. (2009). Trends and Approaches in Lean Health Care. Leadership in Health Services, 22(2), 121139. https://doi.org/10.1108/17511870910953788

Brandao de Souza, L., \& Pidd, M. (2011). Exploring the Barriers to Lean Health Care Implementation. Public Money \& Management, 31(1), 59-66. https://doi.org/10.1080/09540962.2011.545548

Carayon, P., Schoofs Hundt, A., Karsh, B. T., Gurses, A. P., Alvarado, C. J., Smith, M., \& Flatley Brennan, P. (2006). Work System Design for Patient Safety: the SEIPS Model. Quality and Safety in Health Care, 15(1), $150-158$. http://dx.doi.org/10.1136/qshc.2005.015842

Chena, J. C., Lib, Y., \& Shadyc, B. D. (2010). From Value Stream Mapping Toward a Lean/Sigma Continuous Improvement Process: An Industrial Case Study. International Journal of Production Research, 48(4), $1069-1086$. https://doi.org/10.1080/00207540802484911

Ciarniene, R., \& Vienazindiene, M. (2015). An Empirical Study of Lean Concept Manifestation. Procedia - Social and Behavioral Sciences, 207, 225-233. http://dx.doi.org/10.1016/j.sbspro.2015.10.091

Dalmaris, P. (2007). A Framework for the Improvement of Knowledge-intensive Business Processes. Business Process Management Journal, 13(2), 279-305. http://dx.doi.org/10.1108/14637150710740509

De Chernatony, L. \& Harris, F. (2000). Added Value: Its Nature, Roles and Sustainability. European Journal of Marketing, 34(1/2), 39-56. https://doi.org/10.1080/00207540802484911

Does, R. J. M. M., Vermaat, T. M. B., Verver, J. P. S., Bisgaard, S., \& Van den Heuvel, J. (2009). Reducing Start Time Delays in Operating Rooms. Journal of Quality Technology, 41(1), 95-109.

Gardner, J. W., Boyer, K. K., \& Gray, J. V. (2015). Operational and Strategic Information Processing: Complementing Health Care IT Infrastructure. Journal of Operations Management, 33(34), 123-139. https://doi.org/10. 1016/j.jom.2014.11.003

Holtzman, Y. (2011). Business Process Improvement and the Tax Department. Journal of Management Development, 30(1), 49-60. http://dx.doi.org/10.1108/02621711111098361 
Kumar, S., Choe, D., \& Venkataramani, S. (2013). Reflective Practice. Achieving Customer Service Excellence Using Lean Pull Replenishment. International Journal of Productivity and Performance Management, 62(1), 85-109. https://doi.org/10.1108/17410401311285318

Langabeer, J. R., Delli Fraine, J. L., Heineke, J., \& Abbass, I. (2009). Implementation of Lean and Six Sigma Quality Initiatives in Hospitals: A Goal Theoretic Perspective. Operations Management Research, 2, $13-27$. https://doi.org/10.1007/s12063-009-0021-7

Lepak, D. P., Smith, K. G., \& Taylor, M. S. (2007). Value Creation And Value Capture: a Multilevel Perspective. Academy of Management Review, 32(1), 180-94. https://doi.org/10.5465/AMR.2007.23464011

Mast, J., Kemper, B., Does, R. J. M. M., Mandjes, M., \& van der Bijl, Y. (2011). Process Improvement in Healthcare: Overall Resource Efficiency. Quality and Reliability Engineering International, 27, $1095-1106$. http://dx.doi.org/10.1002/qre.1198

Matthews, J. (2013). Adding Value: Getting to the Heart of the Matter. Performance Measurement and Metrics, 14(3), 162-174. http://dx.doi.org/10.1108/PMM-08-2013-0024

McAlearney, A. S., Garman, A. N., Song, P. H., McHugh, M., Robbins, J., \& Harrison, M. (2011). High-performance Work Systems in Health Care Management, part 2: Qualitative Evidence From Five Case Studies. Health Care Manage Rev, 36, 214-26. https://doi.org/10.1097/HMR.0b013e3182100dc4

Morrison, B. (2015). The Problem With Workarounds is That They Work: The Persistence Of Resource Shortages. Journal of Operations Management, 39-40, 79-91. https://doi.org/10.1016/j.jom.2015.07.008

Pekkola, S. \& Ukko, J. (2016). Exploring Added Value Through the Service Process: A Comparative Multiple Case Study. Benchmarking: An International Journal, 23(5), 1249-1260. http://dx.doi.org/10.1108/BIJ-11-2014-0102

Porter, M. E. (2010). What Is Value in Health Care? The New England Journal of Medicine, 363, $2477-2481$. http://dx.doi.org/10.1056/NEJMp1011024

Schiuma, G. \& Carlucci, D. (2012). Managing Knowledge Processes for Value Creation. The Journal of Information and Knowledge Management Systems, 42(1), 4-14. http://dx.doi.org/10.1108/03055721211207815

Svagzdiene, B., Jasinskas, E., Fominiene, V. B., \& Mikalauskas, R. (2013). The situation of learning and prospects for improvement in a tourism organization. Engineering Economics, 24(2), 126-134. https://doi.org/10.5755/ j01.ee.24.2.1386

Tvedt, C., Sjetne, I. S., Helgeland, J., \& Bukholm, G. (2012). A Cross Sectional Study to Identify Organisational Processes Associated with Nurse-Reported Quality and Patient Safety. BMJ Open, 2(6),1-11. http://dx.doi.org/10.1136/ bmjopen-2012-001967

Vveinhardt, J., \& Gulbovaite, E. (2016). Expert evaluation of diagnostic instrument for personal and organizational value congruence. Journal of Business Ethics, 136(3), 481-501. Doi: 10.1007/s10551-014-2527-7

Vveinhardt, J., \& Andriukaitiene, R. (2014) Social responsibility discourse in empirical and theoretical Lithuanian scientific studies. Inzinerine Ekonomika-Engineering Economics, 25(5), 578-588. https://doi.org/10.5755/j01.ee.25.5.4898

Vessella, V. (2015). How Informed Employees Support Process Improvement. Available from internet: https://www.repsly.com/blog/field-team-management/how-informed-employees-support-process-improvement

The article has been reviewed.

Received in October, 2016; accepted in February, 2017. 